\title{
CEO Characteristics and Firm Performance: A Study of Saudi Arabia Listed Firms*
}

\author{
Wafa GHARDALLOU ${ }^{1}$, Hela BORGI ${ }^{2}$, Hibah ALKHALIFAH ${ }^{3}$
}

Received: August 01, 2020 Revised: September 20, 2020 Accepted: October 05, 2020

\begin{abstract}
This paper aims to investigate the impact of chief executive officer's (CEO) attributes on firms' performance. Specifically, it examines the influence of CEOs' education, professional experience, and tenure on Saudi firms' performance. We look at a sample of 120 listed firms on Tadawul stock exchange from 2014 to 2017. Data on financial and accounting variables are obtained from the annual reports of the selected companies. We follow the existing empirical literature and use a panel model and formulate three different equations using the GMM estimator. Findings prove that CEO educational background does matter. In particular, companies employing CEOs with business administration, economics, finance, or accounting degree will perform outstandingly better. Similarly, stock performance gets improved when the $\mathrm{CEO}$ has a postgraduate qualification, i.e., when the $\mathrm{CEO}$ holds an MBA, a master, or a PhD degree. Besides, results reveal that executives who have an experience in a related field will positively affect the firm's performance. Finally, evidence shows that high CEOs tenure improves corporate performance. Overall, these findings demonstrate that executives' attributes are key factors that would explain differences in Saudi firms' performance. These results would help shareholders to make the right decision in selecting CEOs to manage the company.
\end{abstract}

Keywords: Firm Performance, CEO Characteristics, Saudi Listed Firms, Tadawul Stock Exchange

JEL Classification Code: L25, G30, G32

\section{Introduction}

In corporate governance, financial performance has always been a recurring research theme, guided by many

\footnotetext{
*Acknowledgements:

This research project was funded by the Deanship of Scientific Research, Princess Nourah bint Abdulrahman University, through the Program of Research Project Funding After Publication, grant No. (41 - PRFA-P-6).

${ }^{1}$ First Author and Corresponding Author. Assistant Professor, Department of Accounting, College of Business Administration, Princess Nourah bint Abdulrahman University, Riyadh, Saudi Arabia [Postal Address: P.O. Box: 84428, Riyadh, 11671, Saudi Arabia] Email: wafa.ghardallou@gmail.com

${ }^{2}$ Assistant Professor, Department of Accounting, College of Business Administration, Princess Nourah bint Abdulrahman University, Riyadh, Saudi Arabia. Email: hela.borgi@gmail.com

${ }^{3}$ Lecturer, Department of Accounting, College of Business Administration, Princess Nourah bint Abdulrahman University, Riyadh, Saudi Arabia. Email: haalkhalifah@pnu.edu.sa

(c) Copyright: The Author(s)

This is an Open Access article distributed under the terms of the Creative Commons Attribution Non-Commercial License (https://creativecommons.org/licenses/by-nc/4.0/) which permits unrestricted non-commercial use, distribution, and reproduction in any medium, provided the original work is properly cited.
}

concerns. One of the big questions that companies have always raised is how to improve their performance. The creation of value has become one of the main criteria for evaluating companies in an increasingly financialized economy. The requirements in terms of value creation leads to questioning the way in which companies manage or transfer their risks.

Therefore, an abundant literature has emerged in order to study the determinants of firms' performance. This literature has evocated many factors that significantly explain the financial performance (Assenga et al., 2018; Boadi \& Osarfo, 2019). Among these factors, executive directors' (CEO) characteristics play a crucial role (Bandiera et al., 2020; Fernández-Temprano \& Tejerina-Gaite, 2020). Indeed, among the most important players that are involved in this process are the executive managers. Similarly, the success or failure of the company is, almost always, attributed to their managers. In constant evolution, the role of executive managers is to drive growth and manage complexity, while controlling costs. In the same way, recent financial crises have raised the issue of corporate governance effectiveness and particularly top managers' behavior in the company. 
Executive managers take strategic decisions, which are crucial for the firm survival. Their role is increasingly focused on investment issues for growth in order to initiate a deep organizational transformation, with a view to creating value.

In light of the importance of this research theme, the aim of this paper is to empirically assess the role of various CEO features on the performance of Saudi listed firms. Therefore, this study calls into question the role of some selected CEO attributes and mainly, education, professional experience and tenure in explaining differences in Saudi firms' performance.

Despite the fact that this research topic is not totally new, certain features distinguish our study from prior ones. First, after reviewing the literature on firm performance and CEO characteristics, it was noticed that empirical investigations are almost all focused on the US and the European countries (Diks, 2016; Bandiera et al., 2020). To our knowledge, this relationship is not accounted for by the existing empirical work within the Saudi context. Indeed, studies on the Saudi market are mainly focusing on the relationship between the other corporate governance variables such as board composition and size, CEO duality, audit committee and firm performance (Al-Ghamdi \& Rhodes, 2015). This paper tries to fill this gap by exclusively looking at the impact of CEO characteristics on the performance of the Saudi listed firms. Second, the choice of an emerging market like Saudi Arabia is motivated by the fact that the country has recently adopted international financial reporting standards (IFRS), where the adoption of these standards has largely changed the ways firms conduct their business. It has also increased the attraction of the Saudi market for foreign investors. These structural transformations have made Saudi companies relatively special because managers in companies and namely chief executive officers have to adapt to these changes by making the necessary adjustments regarding the definition of the organization's goals and vision. Moreover, it is widely known that Saudi companies are almost all family-owned businesses, which have exemplary CEOs succession strategies (Al-Ghamdi \& Rhodes, 2015). The specificity of the Saudi firms highlights the need to increase the understandability of the relationship between CEO characteristics and firm performance in the Saudi context.

The paper contributes to the literature on firm performance in several ways. First, this study is among the leading studies that have focused on the link between CEO characteristics and firm performance. Especially, it extends previous studies by examining this relationship in the case of an emerging country like Saudi Arabia. Second, it evaluates the effect of the other traditional factors identified in the literature on the performance of Saudi listed firms. Finally, it provides scholars with a starting point to further explore issues related to firm performance operating in emerging markets.
The remainder of this paper is organized as follows. Section 2 develops the theoretical framework and reviews the literature on the link between CEO characteristics and firm performance. The empirical methodology is presented in section 3. Section 4 addresses the empirical results. Section 5 concludes the paper and provides policies and implications of the research.

\section{Literature Review}

\subsection{Theoretical Framework}

The theoretical framework aims to explain the role of the CEO as a decision-maker in the company and how this latter is responsible in shaping the organization performance. In this regard, various theories underline the fact that top management executives are good predictors of firms' financial performance. This paper is particularly built on the agency theory and the stewardship theory as two of the most related corporate governance theories that have focused on explaining the relationship between top managers, shareholders and firm performance (Jensen \& Meckling, 1976; Fama, 1980). These theories are fundamentally linked to the topic of CEO attributes and how top managers' characteristics influence the firm value and likewise the value of the shareholders.

The agency theory is concerned with the relationship between shareholders and top managers in the company. Shareholders are considered as principals whereas top managers as agents. Proponents of this theory advocate that losses arise when managers in the company react in a manner that does not benefit the firm's shareholders (Jensen $\&$ Meckling, 1976). These losses are referred to as agency costs. Basically, the agency theory stipulates that interests inside the firm are not necessary the same given that decision-makers do not have a common objective consisting on rising the shareholders' wealth. Contrary to the agency theory according to which top managers are considered as opportunistic and rent seekers, proponents of the stewardship theory consider that managers are collectivist, honest, and responsible for the company resources (Davis et al., 1997). The stewardship theory stipulates to give more control to managers inside the company given that these latter are more likely to act at the interest of the shareholders by seeking long-term performance of the whole organization. Hence, top management executives can use operational control they have in order to increase the value of the firm and to achieve the shareholders' goals.

This paper attempts to empirically assess the validity of these theories in the Saudi context. Given that control is exerted by CEOs in the company, this study seeks to examine the impact of CEO characteristics such as 
education, tenure, and experience on the firm performance. As the two theories predict various kinds of relationships between these variables, this study will allow to depict the validity of these relationships within the Saudi environment. Ultimately, the theoretical framework underlines the basic mechanisms of the agency and the stewardship theories through which the relationship between CEO characteristics and firm performance may be explained. These relationships will be further illuminated in what follows.

\subsection{CEO Education and Firm Performance}

Prior studies emphasized the importance of the education by the management staff. A valuable human capital in the company is primarily based on the education level of the staff. Especially, a higher CEO's educational background will enhance the value of the company's human capital. Indeed, managers with advanced education level are more able to make adequate decisions in complex environment, a better tolerance of innovative solutions and a good ability to handle the difficulties and ambiguities that may arise (Bantel \& Jackson 1989; Cheng et al., 2020). Accordingly, higher educated CEOs are less likely to experience turnover sine they would make strategic decisions in the company (Deepak \& Rajagopalan, 1998; Altuwaijri \& Kalyanaraman, 2020). Greater stability has a positive effect on the form's financial performance. Overall, higher educational level is a precursor for better managerial effectiveness. Indeed, managers highly educated are better equipped to take optimum decisions (Certo, 2003).

Similarly, a second branch of the literature underlines that managers holding MBA degrees seem to follow less risky strategies, are engaged in short term goals, and are reluctant to adopt innovation. In contrast, executive directors with technical education more likely encourage innovation and establish higher administrative complexity. Finally, firms whose manager holds a degree in economics are characterized by a less administrative complexity (Hambrick \& Mason, 1984)

Regarding the empirical literature, the majority of the empirical studies is aligned with the above theoretical arguments. For instance, Kokeno and Muturi (2016) investigated the impact of CEO characteristics on firm performance using a sample of firms listed in the Nairobi Securities Exchange. Their findings indicate that CEO education and CEO age have a positive and significant effect on firm performance. These results are corroborated by another study, which has been conducted by Deepak and Rajagopalan (1998). The authors examined the effect of CEO attributes on the performance of US manufacturing firms. Results indicate that the education level of the CEO positively affects performance of the companies.

\subsection{CEO Professional Experience, Qualification and Firm Performance}

A second brand of the literature emphasizes the importance of CEO's professional experience in explaining firms' performance variability (Guner et al., 2008). A first stream of the literature reports that directors with good qualification, skills and experience are more likely to enhance the financial performance of the company. In particular, some authors highlight that CEOs' with an expertise in finance, accounting and law are better equipped to take more effective strategic decisions (Serra et al., 2016). In addition, when appointed, a CEO with a high professional experience will provide a better monitoring and will receive a stronger stock market reaction (Erickson et al., 2005). Consequently, managers with good expertise are more solicited by companies (Hayes \& Abernathy, 1980). Based on the above arguments, it is expected that firms hiring CEOs with a professional qualification will have higher performance than firms employing CEOs with no professional qualification.

However, the literature dealing with the effect of CEO experience on firm performance is not conclusive. Indeed, the theory of learning transfer stipulates that knowledge should not be acquired before new learning process takes place (Morrison \& Brantner, 1992). Indeed, it is argued that learning in a new position is much more efficient and rapid when learning acquired in the prior experience did not encounter skills and abilities required in the new position (Morrison \& Brantner, 1992). Particularly, CEOs with prior experience may suffer from negative transfer of learning especially because their past experience may hinder their post-performance. In addition, CEOs with prior experience are more likely to replicate their past success in their current job. However, given that the new position has different characteristics from the previous one, and that actions that led to performance in the previous context may not induce the same results in the new job, this will hinder the financial performance of the company (Hamori \& Koyuncu, 2015). Indeed, firms operating in the same industry may also have culture and operational differences. For instance, it is argued that entrepreneurs that started new ventures are more likely to succeed compared to entrepreneurs that establish a closely related industry venture (Schollhammer, 1991).

\subsection{CEO Tenure and Firm Performance}

Studies vary in their results on what the impact of CEO's tenure should be on firm performance. Some scholars argue a positive relationship between executive's tenure and firm performance, while others state that the relationship is negative or even non-significant. The first school of thought explain the association between CEO tenure and firm performance by the fact that longer experience with 
the company enhances the CEO understanding of the company's effective strategy and consequently causes company performance improving. Indeed, Schwenk (1993) found that longer tenure, which means longer experience with the company, allows CEO to better understand the company's effective strategy since long tenured CEOs are helpful to gain more knowledge, power, and skills that can lead to better control in a risky environment. Consequently, CEOs with long tenure will boost the company performance. In addition, Simsek (2007) stated that greater tenure implies deeper knowledge and advanced skills, which are beneficial to keep the risks under control.

On the other hand, some authors stipulate that CEOs' tenure has a negative effect on firm performance. Finkelstein and Hambrick (1990) claimed that longer tenure CEOs are more likely to pursue traditional strategies. Moreover, longer experience CEOs have more obligations that lead to less effective strategies and cause negative performance. Miller (1991) pointed out that tenure may have both positive and negative effects on performance depending on the CEO's life cycle seasons. Following this view, Wu et al. (2005) argued that during the earlier seasons, CEOs take up new initiatives and expand their knowledge and skills as tenure increases, thus improving firm performance. However, in the later seasons, CEOs become more strongly committed with their own view of the firm, myopically committed to obsolete paradigms, and tend to adapt less to the external environment (Miller, 1991).

Results of the empirical literature are similarly inconclusive. For example, Diks (2016) tested the hypotheses that executive's tenure is positively correlated with firm value. The sample consists of 505 biggest companies in the United States between 2000 and 2015. Results demonstrate that higher tenure improve the financial performance of the selected companies. In contrast, using a sample of 95 CEOs from the top 36 performing public-listed companies from 2009 to 2016, Kusumasari (2018) prove that there is no relationship between the two variables. Finally, Tsai et al. (2006) examined the above relationship using a sample of 304 listed firms in Taiwan. Among the sample companies, 63 were family controlled. The authors found that CEO tenure negatively affect the performance of the firm.

\section{The Empirical Specification}

This paper aims to study the effects of CEO characteristics on firms' performance of Saudi listed firms. Data on financial and accounting variables are obtained from Tadawul stock exchange and particularly from the annual reports of the selected companies. Annual reports include statements of comprehensive income as well as statements of financial position. In addition, data on CEOs' education and experience are taken from the CVs and or social media profiles. The sample consists of 120 listed firms from 2014 to 2017. This study excludes financial firms as well as firms with incomplete information. Financial firms are excluded due to their specific nature in terms of reporting standards.

\subsection{The Dependent Variable}

The dependent variable, which is the firm performance, is measured through three variables. The first variable is return on asset (ROA), the second variable is return on equity (ROE) whereas the third variable is (Tobin's Q). The choice of these variables is first justified by the fact that they are commonly used in the empirical literature. Second, these variables are employed in order to assess different dimensions of financial performance. Specifically, the first two variables measure the accounting performance of the firm whereas the third one proxies its market performance. Return on assets (ROA) is defined as the ratio of the net income divided by the total assets in the period. (ROA) is largely used to measure the financial performance of the firm because it considers the historical background of the company over the year in addition to its operational events. (ROA) indicates how the firm employs its resources to generate an acceptable rate of return.

Therefore, (ROA) is an accounting based performance indicator that illuminates how successful a firm uses its assets. The second variable, which is the return on equity (ROE), is on the other hand measured as the proportion of net income to total equity in the period. (ROE) is a market ratio that measures the return on investment of shareholders. It indicates the amount of profit as a percentage of shareholders' equities. Consequently, (ROE) measures the ability of a firm to generate income from its shareholders' investments in the company. Finally, the third proxy of financial performance (Tobin's Q) is defined as the sum of the market value of equity and the book value of total assets minus the book value of equity, divided by the book value of total assets. This variable is used as a proxy of the company's market performance. Indeed, when the variable is comprised between 0 and 1 , this means that the market value is lower than the replacement costs of the company's assets. In this case, the stock is considered as undervalued. In contrast, when the ratio is greater than 1, it means that the stock is overvalued. In addition, unlike the first two measures which are short-term performance measures, (Tobin's Q) is a long-term performance measure because it measures the ability of the firm to enhance its performance over the long run period (Caton et al., 2001).

\subsection{The Independent Variables}

As mentioned earlier, this study aims to examine the role of CEOs characteristics in explaining financial performance variability. Although, prior studies considered many characteristics of $\mathrm{CEO}$, this paper is concentrated on 
selected features of CEOs that are in line with the Saudi context. Particularly, the study considers CEO education, $\mathrm{CEO}$ tenure, and $\mathrm{CEO}$ professional experience. Following Morresi (2017), CEO education is measured by two different variables. First, a dummy variable (Postgraduate) that takes the value of 1 if the CEO has a master, MBA or a $\mathrm{PhD}$ degree, 0 otherwise. Second, we consider the field of the study since a CEO with a degree in business administration, economics, finance or accounting is naturally better equipped to manage the company. The second dummy variable (Field) takes the value of 1 for CEOs who have graduated in business administration and economics fields, and 0 otherwise. On the other hand, CEO tenure (Tenure) is measured by the number of years since CEO appointment (Murphy \& Zimmerman, 1993). As underlined in the above literature, the effect of this variable on firm performance is not clear since previous studies reported that results regarding the effect of CEO tenure on firm performance are not conclusive. Finally, CEO professional experience is measured by a dummy variable (Experience) that takes the value of 1 if the CEO has a related industry experience to its current position, and 0 otherwise. Based on the above literature, the effect of CEO industry experience on financial performance is not conclusive.

\subsection{The Control Variables}

We follow the literature and include a set of control variables that are commonly used in the previous studies (Nguyen \& Nguyen, 2020). We particularly include four control variables: the firm size (Size) is measured by the natural logarithm of total assets at the year end; the firm leverage (Leverage) using the ratio of total debts to total assets; the growth of the company sales (Sales-Growth) calculated as the difference of sales of the current year and the previous year divided by sales of the current year; the tangibility of assets (Tangible) measured as the ratio of fixed assets to total asset.

\subsection{The Econometric Model}

In order to estimate the effects of CEOs' characteristics on firm performance, we follow the existing empirical literature and use a panel model. Panel data are commonly used in order to treat unobserved heterogeneity problem (Qaiser \& Al-Mamun, 2017). According to many previous studies (Arora \& Sharma, 2016), we estimate the equations (1), (2) and (3) using the GMM estimator developed by Arellano and Bond (1991). In our econometric estimates, the variables assumed to be exogenous are CEOs characteristics. All other explanatory variables are assumed to be endogenous and instrumented by their lags of no more than three periods. We retain the following specifications:

$$
\begin{aligned}
\text { ROA }_{\mathrm{it}}= & \beta_{0}+\beta_{1} \text { Postgraduate }_{\mathrm{i}}+\beta_{2} \text { Field }_{\mathrm{i}}+\beta_{3} \text { Tenure }_{\mathrm{it}} \\
& +\beta_{4} \text { Experience }_{\mathrm{i}}+\beta_{5} \mathrm{Z}_{\mathrm{it}}+\mathrm{e}_{\mathrm{it}} \\
\mathrm{ROE}_{\mathrm{it}}= & \beta_{0}+\beta_{1} \text { Postgraduate }_{\mathrm{i}}+\beta_{2} \text { Field }_{\mathrm{i}}+\beta_{3} \text { Tenure }_{\mathrm{it}} \\
& +\beta_{4} \text { Experience }_{\mathrm{i}}+\beta_{5} \mathrm{Z}_{\mathrm{it}}+\mathrm{e}_{\mathrm{it}}
\end{aligned}
$$

Tobin's $\mathrm{Q}_{\mathrm{it}}=\beta_{0}+\beta_{1}$ Postgraduate $_{\mathrm{i}}+\beta_{2}$ Field $_{\mathrm{i}}+\beta_{3}$ Tenure $_{\mathrm{it}}$ $+\beta_{4}$ Experience $_{\mathrm{i}}+\beta_{5} Z_{\mathrm{it}}+\mathrm{e}_{\mathrm{it}}$

Where the subscript $i$ indexes firms and the subscript $t$ indexes time periods. $Z_{\text {it }}$ is the vector of control variables, and $\mathrm{e}_{\mathrm{it}}$ is the error term.

\section{Results}

\subsection{Descriptive Statistics}

The descriptive statistics provided in this paragraph aim to compare the financial performance of firms according to the CEO characteristics. We compare the financial performance using two measures of firm performance. The first one is an accounting measure (ROA) whereas the second one is a market measure (Tobin-Q). Mean and standard deviations of group 0 and group 1 are displayed with the different $\mathrm{p}$ values. Descriptive results in Table 1 demonstrate that firms who's CEOs hold a degree in business administration, economics, finance or accounting better perform than other companies. In addition, results show that companies whose CEOs have a related experience have a greater financial performance. This positive relationship is also confirmed when the CEO's number of years after being appointed is higher. Finally, results in Table 1 show that the variable (Postgraduate) reacts differently. Indeed, CEOs that hold a postgraduate degree will only increase the stock market performance of the company. Results are not significant when the accounting measure (ROA) is used.

Finally, we report in Table 2 descriptive statistics showing the mean, the standard deviation, the minimum and the maximum values of all the variables used in the model.

\subsection{Correlation Matrix}

These descriptive statistics can be deepened by examining the correlations between the explanatory variables and the endogenous variable measuring the financial performance of the firm. The correlation matrix is given in Table 3 . The latter shows that CEO characteristics variables have a positive correlation with the firm performance indicators. The only exception is the (Postgraduate) variable, which is negatively correlated with ROA and ROE variables. In addition, all of the control variables are statistically correlated with the dependent variable and have the expected sign. Furthermore, the explanatory variables are weakly correlated with each other, which justifies their inclusion in the same model. 
Table 1: Financial performance (average and standard deviation) based on the CEO characteristics

\begin{tabular}{|c|c|c|c|c|c|}
\hline CEO attributes & Firm performance & Groups & Mean & Sd & $P$ value \\
\hline Postgraduate & ROA & $\begin{array}{l}\text { Group }=0 \\
\text { Group }=1\end{array}$ & $\begin{array}{l}0.098 \\
0.189 \\
\end{array}$ & $\begin{array}{l}0.073 \\
0.087 \\
\end{array}$ & 0.268 \\
\hline Postgraduate & Tobin-Q & $\begin{array}{l}\text { Group }=0 \\
\text { Group }=1\end{array}$ & $\begin{array}{l}0.387 \\
0.420 \\
\end{array}$ & $\begin{array}{l}0.196 \\
0.124\end{array}$ & 0.061 \\
\hline Field & ROA & $\begin{array}{l}\text { Group }=0 \\
\text { Group }=1\end{array}$ & $\begin{array}{l}0.053 \\
0.059 \\
\end{array}$ & $\begin{array}{l}0.087 \\
0.083\end{array}$ & 0.062 \\
\hline Field & Tobin-Q & $\begin{array}{l}\text { Group }=0 \\
\text { Group }=1\end{array}$ & $\begin{array}{l}0.222 \\
0.399 \\
\end{array}$ & $\begin{array}{l}0.102 \\
0.132 \\
\end{array}$ & 0.064 \\
\hline Experience & ROA & $\begin{array}{l}\text { Group }=0 \\
\text { Group }=1\end{array}$ & $\begin{array}{l}0.045 \\
0.065\end{array}$ & $\begin{array}{l}0.061 \\
0.090 \\
\end{array}$ & 0.013 \\
\hline Experience & Tobin-Q & $\begin{array}{l}\text { Group }=0 \\
\text { Group }=1\end{array}$ & $\begin{array}{l}0.456 \\
0.321 \\
\end{array}$ & $\begin{array}{l}0.102 \\
0.120 \\
\end{array}$ & 0.166 \\
\hline Tenure & ROA & $\begin{array}{l}\text { Group }=0 \\
\text { Group }=1\end{array}$ & $\begin{array}{l}0.035 \\
0.059\end{array}$ & $\begin{array}{l}0.043 \\
0.065\end{array}$ & 0.085 \\
\hline Tenure & Tobin-Q & $\begin{array}{l}\text { Group }=0 \\
\text { Group }=1\end{array}$ & $\begin{array}{l}0.456 \\
0.568 \\
\end{array}$ & $\begin{array}{l}0.123 \\
0.023 \\
\end{array}$ & 0.034 \\
\hline
\end{tabular}

Note: Two-sample $\mathrm{t}$ test with equal variances.

Table 2: Descriptive statistics

\begin{tabular}{|c|c|c|c|c|c|}
\hline Variable & Obs & Mean & Std. Dev. & Min & Max \\
\hline Tobin-Q & 433 & .411 & .216 & .0147 & .889 \\
\hline ROA & 450 & .056 & .085 & -.511 & .377 \\
\hline ROE & 450 & .082 & .202 & -2.768 & .603 \\
\hline Tenure & 362 & 5.356 & 4.900 & 0 & 23 \\
\hline Experience & 357 & .638 & .481 & 0 & 1 \\
\hline Field & 453 & .459 & .498 & 0 & 1 \\
\hline Postgraduate & 432 & 0557 & .497 & 0 & 1 \\
\hline Leverage & 441 & .400 & .205 & .013 & .889 \\
\hline Sales & 325 & -.124 & 2.274 & -26.212 & 7.881 \\
\hline Tangible & 450 & .482 & .233 & .0124 & .990 \\
\hline Size & 450 & 14.781 & 1.537 & 11.307 & 19.915 \\
\hline
\end{tabular}

Table 3: Correlation matrix

\begin{tabular}{|l|c|c|c|c|c|c|c|c|c|c|}
\hline & Tobin & ROA & ROE & Tenure & Exp & Field & Postg & Lev & Sale & Tang \\
\hline Tobin & 1 & & & & & & & & & \\
\hline ROA & -0.327 & 1 & & & & & & & \\
\hline ROE & -0.215 & 0.856 & 1 & & & & & & \\
\hline Tenure & 0.061 & 0.027 & 0.086 & 1 & & & & & \\
\hline Exp & 0.052 & 0.117 & 0.058 & 0.143 & 1 & & & & \\
\hline Field & -0.053 & 0.030 & 0.048 & -0.159 & -0.141 & 1 & & & & \\
\hline Postg & 0.076 & -0.016 & -0.027 & -0.104 & 0.163 & 0.280 & 1 & & \\
\hline Lev & 0.977 & -0.286 & -0.185 & 0.032 & 0.045 & -0.046 & 0.047 & 1 & & \\
\hline Sale & 0.003 & 0.294 & 0.503 & 0.019 & 0.022 & 0.027 & 0.052 & -0.001 & 1 & \\
\hline Tang & 0.190 & 0.004 & 0.005 & 0.212 & 0.064 & -0.037 & 0.038 & 0.124 & 0.078 & 1 \\
\hline Size & 0.440 & 0.011 & 0.042 & 0.046 & 0.113 & 0.101 & 0.200 & 0.360 & 0.039 & 0.221 \\
\hline
\end{tabular}




\subsection{Estimation Results}

The results of our estimates are presented in Table 4. Specification (1) includes the ROA as a dependent variable whereas specifications (2) and (3) employ respectively ROE and Tobin's $Q$ as endogenous variables. As mentioned above, the first two measures reflect the corporate performance from an accounting perspective whereas the third measure reflects the financial performance based on the market perception. All the specifications are estimated using the system-GMMs. Before interpreting the results of the explanatory variables, it is important to note that from Table 4, Hansen overidentification tests confirm the validity of the instruments, while the Arellano Bond AR (2) tests verify the absence of the second-order autocorrelation of the residuals of the model in first differences. Moreover, Table 4 demonstrates the strong significance of the autoregressive term. Indeed, the lagged dependent variable is significant when using the different measures of financial performance. This result confirms our choice of a dynamic specification.

Moving to the role of the main explicative variables, i.e., CEOs' characteristics variables, results in Table 4 demonstrate that the variable (Tenure) has a positive and significant coefficient through the majority of the specifications. This finding provides evidence that increasing the number of years after the CEO appointment will enhance the financial performance of the firm. This result confirms a part of the previous studies that proved a positive relationship between executive tenure and firm performance (Wu et al., 2005). This is because CEOs with higher tenure are more willing to invest in higher risky projects, which will normally yield higher return. In addition, CEOs with longer tenure will keep their strategy stable and unchanged which is likely to increase the commitment towards the firm and results into higher firm performance.

The role of the CEO related experience is also confirmed. Indeed, results in Table 4 show that the coefficient associated with the variable (experience) is positive and significant through all the specifications. Therefore, companies whose executives have an experience in a related field will better perform. Our results confirm some of the previous studies that found a positive relationship between the executive professional experience and corporate performance (Erickson et al., 2005). Therefore, directors with a related experience are more likely to enhance the financial performance of the company. This result is explained by the fact that when appointed, a CEO with a high professional experience will provide a better monitoring and will receive a stronger stock market reaction. Consequently, Managers with good expertise are much solicited by companies (Hayes \& Abernathy, 1980).

Regarding the role of the education variables, results in Table 4 demonstrate that the impact of CEOs education level is different according to the measure of financial performance. First, the variable (Field) has a positive and significant coefficient through all the specifications. Hence, executives' field of study significantly impacts the financial performance of the firm. In particular, the findings prove that CEOs that hold a degree in business administration, economics, finance or accounting will enhance the performance of the company. This is because these latter are naturally better equipped to manage the company. Indeed, executive directors with training in management or economics are able to make adequate decisions in complex environment, will better tolerate innovative solutions and will handle difficulties and ambiguities that may arise (Bantel \& Jackson, 1989). In addition, a relevant literature underlines that CEOs who rather have technical education are more likely to establish higher administrative complexity, which will hinder the corporate performance (Hambrick \& Mason, 1984).

Findings related to the second proxy of education are different. Indeed, coefficient associated to postgraduate is not significant when using ROA and ROE, whereas the coefficient becomes positive and significant when using Tobin's Q measure. These results indicate that companies that employ executive directors who are post graduated i.e. who hold an MBA, a master, or a $\mathrm{PhD}$ degree will not improve the company financial performance. However, it seems that CEOs with high education background significantly enhance the firm value. This is because the coefficient associated to Tobin's Q is positive and significant. These findings are aligned with a related empirical literature (Gottesman \& Morey, 2010). These findings confirm the fact that investors prefer CEOs who hold postgraduate degrees, which is reflected in higher stock market return. Indeed, CEOs with postgraduate degrees bring intangible benefits such as larger connections and better reputation, which materializes in superior market performance. In addition, these results may be explained by the fact that the market value of the firm that hires CEOs with more advanced education reflects more opportunities of investments and a diversification of sources of financing that are related to the CEOs' business network created during the years at the university. Finally, a last plausible explanation is that the CEO education level may affect in the long run firm performance (Tobin's Q), while it does not play a role in the short run (ROA and ROE).

Therefore, there is no evidence that Saudi firms whose CEOs hold postgraduate degrees outperform companies hiring law graduates CEOs. Nevertheless, the market value of Saudi listed firms that hires CEOs with excellent education background is higher than firms employing undergraduate executives. These findings suggest that CEO education can significantly improve the firm value, but cannot affect its accounting profitability. These results may be explained by the fact that investors perceive high level of education of firms' CEOs as a good motivation to invest in the company which enhances the firm's value. In contrast, holding a high degree does not seem to offer any guarantee of managing firms successfully. 
Table 4: Estimation results

\begin{tabular}{|c|c|c|c|}
\hline & (1) & $(2)$ & (3) \\
\hline & ROA & ROE & Tobin-Q \\
\hline \multirow[t]{2}{*}{ LagROA } & $0.608^{* * *}$ & & \\
\hline & $(0.000)$ & & \\
\hline \multirow[t]{2}{*}{ Tenure } & 0.000813 & $0.00257^{* *}$ & $0.00344^{* * *}$ \\
\hline & $(0.154)$ & $(0.018)$ & $(0.000)$ \\
\hline \multirow[t]{2}{*}{ Experience } & $0.0118^{*}$ & $0.0271^{* *}$ & $0.00733^{* *}$ \\
\hline & $(0.067)$ & $(0.029)$ & $(0.00332)$ \\
\hline \multirow[t]{2}{*}{ Field } & $0.0491^{*}$ & $0.123^{* * *}$ & $0.0947^{* * *}$ \\
\hline & $(0.058)$ & $(0.008)$ & $(0.0111)$ \\
\hline \multirow[t]{2}{*}{ Postgraduate } & -0.0226 & -0.0519 & $0.00611^{\text {** }}$ \\
\hline & $(0.003)$ & $(0.000)$ & $(0.00286)$ \\
\hline \multirow[t]{2}{*}{ Leverage } & $-0.102^{* * *}$ & $-0.165^{\star * *}$ & $1.004^{* * *}$ \\
\hline & $(0.000)$ & $(0.000)$ & $(0.0120)$ \\
\hline \multirow[t]{2}{*}{ Sales-growth } & $0.00541^{* * *}$ & $0.00897^{* * *}$ & $0.00431^{*}$ \\
\hline & $(0.000)$ & $(0.000)$ & $(0.091)$ \\
\hline \multirow[t]{2}{*}{ Tangible } & $-0.0364^{* *}$ & -0.00221 & $-0.0468^{* * *}$ \\
\hline & $(0.018)$ & $(0.917)$ & $(0.005)$ \\
\hline \multirow[t]{2}{*}{ Size } & $0.0181^{* * *}$ & $0.0175^{\star * *}$ & 0.00190 \\
\hline & $(0.005)$ & $(0.000)$ & $(0.00524)$ \\
\hline \multirow[t]{2}{*}{ LagROE } & & $0.554^{* * *}$ & \\
\hline & & $(0.000)$ & \\
\hline \multirow[t]{2}{*}{ LagTobin-Q } & & & $0.0198^{*}$ \\
\hline & & & $(0.068)$ \\
\hline \multirow[t]{2}{*}{ Constant } & $-0.219^{* * *}$ & $-0.228^{* * *}$ & -0.0789 \\
\hline & $(0.006)$ & $(0.000)$ & $(0.0613)$ \\
\hline Observations & 248 & 248 & 240 \\
\hline Number of firms & 96 & 96 & 93 \\
\hline $\begin{array}{l}\text { Instruments } \\
\text { Hansen: } p \text {-value } \\
\text { AR(1): } p \text {-value } \\
\text { AR(2): } p \text {-value }\end{array}$ & $\begin{array}{c}17 \\
0.435 \\
0.000 \\
0.398 \\
\end{array}$ & $\begin{array}{c}14 \\
0,585 \\
0.001 \\
0.233 \\
\end{array}$ & $\begin{array}{c}16 \\
0.765 \\
0.082 \\
0.111 \\
\end{array}$ \\
\hline
\end{tabular}

Note: The figures in parentheses are $p$ values. ${ }^{* * *},{ }^{* *},{ }^{*}$ denote significant coefficients respectively at $1 \%, 5 \%$, and $10 \%$.

a: Test the null hypothesis of the appropriate set of instruments. Based on these values, the null hypothesis of the validity of instruments at the usual risk thresholds cannot be rejected.

b: Test for first-order serial correlation.

c: Test for second-order serial correlation. Based on these values, we cannot reject the null hypothesis of absence of second-order autocorrelation of the residuals of the prime difference model. 


\section{Discussion and Conclusion}

This paper is in line with the stream of literature that has examined the determinants of companies' performance. Specifically, this study seeks to examine the particular role of CEOs' characteristics on shaping the Saudi firms' performance. To do this, the empirical analysis was based on a dynamic panel data model, in which we have introduced a number of variables that reflect the characteristics of CEOs such as CEO education, CEO tenure, and CEO related experience. The choice of the dynamic specification is justified by the fact that the model includes the dependent variable as an explanatory variable in addition to the various control variables.

Regarding the education variables, results demonstrate that the impact of CEOs education is different depending on the education background and level. First, executives' education background is found to affect positively and significantly the financial performance of the firm. In particular, findings prove that CEOs that hold a degree in business administration, economics, finance or accounting will enhance the performance of the company. However, findings related to the second proxy of education, i.e., the level of education, are different. Indeed, results indicate that executive directors who are post graduated that is CEOs who hold an MBA, a master, or a PhD degree do not affect the company's financial performance. However, findings prove that post-graduate CEOs significantly enhance the firm value (measured by Tobin's Q). Therefore, the market value of Saudi listed firms that hire CEOs with advanced education level is higher than firms employing undergraduate executives. These results are explained by the fact that investors perceive high level of education of firms' CEOs as a good motivation to invest in the company. Moreover, we found that the role of the CEO related experience is also confirmed. Therefore, companies whose executives have an experience in a related field will better perform. Finally, results indicate that when the number of years after the CEO appointment increase, financial performance of the firm will be improved.

This paper expands the empirical literature on the determinants of firm performance in Gulf countries and namely in Saudi Arabia. Based on the above results, it seems that some executives' attributes are key factors that would explain differences in Saudi firm performance. This study would be substantive for people inside the company who are responsible for hiring decisions. Particularly, it may provide valuable insights to shareholders by helping them making the right decision when selecting CEOs to run the company. Given that Saudi Arabia companies are almost family owned businesses, which have exemplary CEOs succession strategy; this study encourages Saudi shareholders to consider various features in their recruitment policy. The decision to hire CEOs should be basically based on executives' characteristics such as education, tenure and experience rather than simply following family succession plans. That said, appointing family members with the requisite traits is also a good strategy. Persons in charge of recruiting are encouraged to enroll CEOs with a related experience, i.e., executives with prior experience who are able to replicate their past success in their current job, as this may be of a great value for the firm. Similarly, it is highly recommended to select executives with an education background in business administration, economics, finance or accounting rather than in operating related subjects when there is a need. Likewise, from the viewpoint of stock market performance, recruiting postgraduate CEOs is a good strategy that increases the Saudi firm value. Another important aspect to consider is that Saudi companies are encouraged to increase the tenure of executives by for example avoiding frequent CEOs replacements in order to improve their financial performance. Additionally, this would help the company's stakeholders to reduce some of the agency issues that may arise with insiders and especially executive directors within the company. Globally, this would enhance the Saudi competitive power in the global market.

\section{References}

Al-Ghamdi, M., \& Rhodes, M. (2015). Family Ownership, Corporate Governance and Performance: Evidence from Saudi Arabia. International Journal of Economics and Finance, 7(2), 78-89. DOI: 10.5539/ijef.v7n2p78

Altuwaijri, B. M., \& Kalyanaraman, L. (2020). CEO EducationPerformance Relationship: Evidence from Saudi Arabia. Journal of Asian Finance, Economics and Business, 7(8), 259-268. https://doi.org/10.13106/jafeb.2020.vol7.no8.259

Arellano, M., \& Bond, S. (1991). Some tests of Specification for panel data: Monte Carlo evidence and an application to employment equations. Review of Economic Studies, 58(2), 277-298. https://doi.org/10.2307/2297968

Arora, A., \& Sharma, C. (2016). Corporate governance and firm performance in developing countries: evidence from India. Corporate Governance, 16(2), 420-436. DOI: 10.1108/CG-012016-0018

Assenga, M. P., Aly, D., \& Hussainey, K. (2018). The impact of board characteristics on the financial performance of Tanzanian firms. Corporate Governance: The International Journal of Business in Society, 18(6), 1089-1106. DOI: 10.1108/CG-092016-0174

Bandiera. O., Prat. A., Hansen. S., \& Sadun. S. (2020). CEO Behavior and Firm Performance. Journal of Political Economy, 128(4), 1325-1369. DOI: 10.1086/705331

Bantel, A. B., \& Jackson, S. E. (1989). Top management and innovations in banking: Does the composition of the top team 
make a difference? Strategic Management Journal, 10(S1), 107-124. DOI: $10.1002 / \mathrm{smj} .4250100709$

Boadi, I., \& Osarfo, D. (2019). Diversity and return: the impact of diversity board members' education on performance. Corporate Governance: The International Journal of Business in Society, 19(4), 824-842. DOI: 10.1108/CG-01-2019-0017

Caton, G., Goh, J., \& Donaldson, J. (2001). The Effectiveness of Institutional Activism. Financial Analysts Journal, 57(4), 21-26. DOI: 10.2469/faj.v57.n4.2462

Certo, S. T. (2003). Influencing initial public offering investors with prestige: signaling with board structures. The Academy of Management Journal, 28(3), 432-446. https://doi. org/10.2307/30040731

Cheng, T. Y., Li, Y., Lin, Y., \& Chinh, H. (2020). Does the fit of managerial ability with firm strategy matters on firm performance. Journal of Asian Finance, Economics and Business, 7(4), 9-19. https://doi.org/10.13106/jafeb.2020.vol7. no4.9

Davis, J., Schoorman, R., \& Donaldson, L. (1997). Towards a stewardship theory of management. Academy of Management Review, 22(1), 20-47. https://doi.org/10.5465/ amr.1997.9707180258

Deepak, K. D., \& Rajagopalan, N. (1998). Industry structure and CEO characteristics: An empirical study of succession events. Strategic Management Journal, 19(9), 833-852. https:// doi.org/10.1002/(SICI)1097-0266(199809)19:9<833::AIDSMJ971>3.0.CO;2-V

Diks, J. (2016). The impact of CEO characteristics on firm value. Master thesis, Tilburg School of Economics \& Management.

Erickson, J., Park, Y. W., Reising, J., \& Shin, H. H. (2005). Board composition and firm value under concentrated ownership: the Canadian evidence. Pacific-Basin Finance Journal, 13(4), 387-410. https://doi.org/10.1016/j.pacfin.2004.11.002

Fama, E. F. (1980). Agency problems and the theory of the firm. Journal of Political Economy, 88(2), 288-307. http://dx.doi. org/10.1086/260866

Fernández-Temprano, M., \& Tejerina-Gaite, F. (2020). Types of director, board diversity and firm performance. Corporate Governance, 20(2), 324-342. DOI: 10.1108/CG-03-2019-0096

Finkelstein, S., \& Hambrick, D.C. (1990). Top-management-team tenure and organizational outcomes: The moderating role of managerial discretion. Administrative Science Quarterly, 35(3), 484-503. https://doi.org/10.2307/2393314

Gottesman, A. A., \& Morey, M. R. (2010). CEO educational background and firm financial performance. Journal of Applied Finance, 20(2), 1-13. https://ssrn.com/abstract=2693079

Guner, A. B., Malmendler, U., \& Tate, G. (2008). Financial expertise of directors. Journal of Financial Economics, 88(2), 323-354. https://doi.org/10.1016/j.jfineco.2007.05.009

Hambrick, D. C., \& Mason, P. A. (1984). Upper Echelons: The Organization as a Reflection of Its Top Managers. Academy of Management Review, 9(2), 193-206. DOI:10.5465/ amr.1984.4277628

Hamori, M., \& Koyuncu, B. (2015). Experience matters? The impact of prior CEO experience on firm performance. Human Resource Management, 54(1), 23-44. https://doi.org/10.1002/ hrm. 21617

Hayes, R. H., \& Abernathy, W. J. (1980). Managing our way to economic decline. Harvard Business Review, 58(4), 67-77.

Jensen, M. C., \& Meckling, W. H. (1976). Theory of the firm: managerial behavior, agency costs and ownership structure. Journal of Financial Economics, 3(4), 305-360. https://doi. org/10.1016/0304-405X(76)90026-X

Kokeno, S. O., \& Muturi, W. (2016). Effect of chief executive officer's characteristics on the financial performance of firms listed at the Nairobi Securities Exchange. International Journal of Economics, Commerce and Management, 4(7), 307-318.

Kusumasari, L. (2018). Functions, Age, Education, Tenure of CEO, and Employee Commitment Toward Firm Performance. KnE Social Sciences, 3(10), 64-73. DOI: 10.18502/kss.v3i10.3361

Miller, D. (1991). Stale in the saddle: CEO tenure and the match between organization and environment. Management Science, 37(1), 34-52. https://doi.org/10.1287/mnsc.37.1.34

Morresi, O. (2017). How much is CEO Education Worth to a Firm? Evidence from European Firms. PSL Quarterly Review, 70(282), 311-353. DOI: https://doi.org/10.13133/20373643_70.282_4

Morrison, R. F., \& Brantner, T. M. (1992). What enhances or inhibits learning a new job? A basic career issue. Journal of Applied Psychology, 77(6), 926-940. https://doi.org/10.1037/00219010.77.6.926

Murphy, K. J., \& Zimmerman, J. L. (1993). Financial performance surrounding CEO turnover. Journal of Accounting and Economics, 16, 273-315. https://doi.org/10.1016/01654101(93)90014-7

Nguyen, T. N. L., \& Nguyen, V. C. (2020). The determinants of profitability in listed enterprises: a study from Vietnamese stock exchange. Journal of Asian Finance, Economics and Business, 7(1), 47-58. https://doi.org/10.13106/jafeb.2020.vol7.no1.47.

Qaiser, R.., \& AL-Mamun, A. (2017). The Impact of Ownership Concentration on Firm Performance: Evidence from an Emerging Market. Emerging Economy Studies, 3(1), 34-53. DOI: $10.1177 / 2394901517696647$

Schollhammer, H. (1991). Incidence and Determinants of Multiple Entrepreneurship. In: N. C. Churchill, W. D. Bygrave, J. G. Covin, D. P. Slevin and W. E. Wetzel (Eds.), Frontiers of Entrepreneurship Research Wellesley (pp. 11-24). Wellesley, MA: Babson College.

Schwenk, C. (1993). Management tenure and explanations for success and failure. Omega, 21(4), 449-456. https://doi. org/10.1016/0305-0483(93)90077-X

Serra, F. R., Três, G., \& Ferreira, M. P. (2016). The 'CEO' effect on the performance of Brazilian companies: an empirical study 
using measurable characteristics. European Management Review, 13(3), 193-205. https://doi.org/10.1111/emre.12079

Simsek, Z. (2007). CEO tenure and organizational performance: an intervening model. Strategic Management Journal, 28(6), 653662. https://doi.org/10.1002/smj.599

Tsai, W. H., Hung J. H., Kuo Y. C., \& Kuo L. (2006). CEO Tenure in Taiwanese Family and Nonfamily Firms: An Agency Theory
Perspective. Family Business Review, 19(1), 11-28. https://doi. org/10.1111/j.1741-6248.2006.00057.x

Wu, S., Levitas, E., \& Priem, R. L. (2005). CEO tenure and company invention under differing levels of technological dynamism. Academy of Management Journal, 48(5), 859-873. https://doi.org/10.5465/amj.2005.18803927 